\title{
Article \\ Use of Black Poplar Leaves for the Biomonitoring of Air
Pollution in an Urban Agglomeration
}

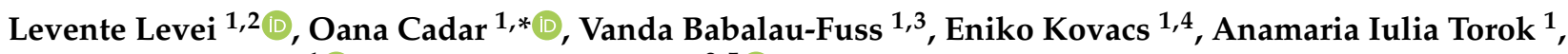 \\ Erika Andrea Levei ${ }^{1}\left(\mathbb{D}\right.$ and Alexandru Ozunu ${ }^{2,5}$
}

1 INCDO-INOE 2000, Research Institute for Analytical Instrumentation, 67 Donath Street, RO-400296 Cluj-Napoca, Romania; levente.levei@icia.ro (L.L.); vanda.fuss@icia.ro (V.B.-F.); eniko.kovacs@icia.ro (E.K.); iulia.torok@icia.ro (A.I.T.); erika.levei@icia.ro (E.A.L.)

2 Faculty of Environmental Sciences and Engineering, Babes-Bolyai University, 30 Fantanele Street, RO-400294 Cluj-Napoca, Romania; alexandru.ozunu@ubbcluj.ro

3 Faculty of Food Science and Technology, University of Agricultural Science and Veterinary Medicine, 3-5 Calea Manastur Street, RO-400372 Cluj-Napoca, Romania

4 Faculty of Horticulture, University of Agricultural Science and Veterinary Medicine, 3-5 Calea Manastur Street, RO-400372 Cluj-Napoca, Romania

5 DIMTEC, University of the Free State, Nelson Mandela Street, Bloemfontein SA-9300, South Africa

* Correspondence: oana.cadar@icia.ro

Citation: Levei, L.; Cadar, O.; Babalau-Fuss, V.; Kovacs, E.; Torok, A.I.; Levei, E.A.; Ozunu, A. Use of Black Poplar Leaves for the Biomonitoring of Air Pollution in an Urban Agglomeration. Plants 2021, 10, 548. https://doi.org/10.3390/ plants10030548

Received: 15 February 2021

Accepted: 11 March 2021

Published: 14 March 2021

Publisher's Note: MDPI stays neutral with regard to jurisdictional claims in published maps and institutional affiliations.

Copyright: (C) 2021 by the authors. Licensee MDPI, Basel, Switzerland. This article is an open access article distributed under the terms and conditions of the Creative Commons Attribution (CC BY) license (https:/ / creativecommons.org/licenses/by/ $4.0 /)$.

\begin{abstract}
Trees are considered to be an effective tool for metal pollution biomonitoring. In the present study, the concentration of metals $(\mathrm{Cu}, \mathrm{Pb}, \mathrm{Zn}, \mathrm{Cd}, \mathrm{Co}, \mathrm{Ni}, \mathrm{Fe}, \mathrm{Mn}$, and $\mathrm{Al})$ in black poplar leaves (Populus nigra L.), together with the concentration of $\mathrm{PM}_{10}, \mathrm{PM}_{2.5}, \mathrm{PM}_{1}$, and total suspended particles (TSP), was used for the air pollution biomonitoring in 12 sites from various areas of ClujNapoca city, Romania. The concentration of $\mathrm{PM}_{10}$ in the air was high, but their metal content was low. However, $\mathrm{Cu}, \mathrm{Pb}$, and $\mathrm{Zn}$ were moderately enriched, while $\mathrm{Cd}$ was highly enriched in $\mathrm{PM}_{10}$ due to anthropogenic sources. The average metal concentration in leaves decreased in the order $\mathrm{Zn}>>\mathrm{Fe}>\mathrm{Mn}>\mathrm{Al}>\mathrm{Pb}>\mathrm{Ni}>\mathrm{Cu}>\mathrm{Co}>\mathrm{Cd}$ and increased with the increase of $\mathrm{PM}_{10}$ concentration, indicating that poplar leaves are sensitive to air pollution. The principal component analysis indicated that traffic, waste burning, road dust resuspension, and soil contamination are the main anthropogenic sources of metals in poplar leaves. The results indicated that black poplar leaves are a suitable biomonitoring tool for metal pollution, in urban environments.
\end{abstract}

Keywords: metals; $\mathrm{PM}_{10} ; \mathrm{PM}_{2.5} ; \mathrm{PM}_{1} ;$ Populus nigra

\section{Introduction}

Metals are important constituents for a wide range of commodities in our daily life, therefore, every human activity that produces and uses these commodities has the potential to release metals into the environment [1]. Pollution with metals negatively impacts both the ecosystems and human health due to its high toxicity, high bioaccumulation rates, and low biodegradation potential [2-4].

Air pollution is recognized as one of the factors that decrease life expectancy and increase the incidence of cardiovascular and respiratory pathologies as the fine and ultrafine particulates can penetrate deeply into the lungs [5,6]. Air pollution with particulate matter (PM), with aerodynamic diameters $<10 \mu \mathrm{m}\left(\mathrm{PM}_{10}\right), 2.5 \mu \mathrm{m}\left(\mathrm{PM}_{2.5}\right)$, and $1 \mu \mathrm{m}$ $\left(\mathrm{PM}_{1}\right)$ are the main challenges, especially in urban agglomerations, where besides the industrial activities, vehicular traffic (exhaust emissions, tire and brake wear, mechanical frictions, and lubricants), surface runoff, re-suspended dust, and fossil fuel combustion are considered important pollution sources [7-9]. Depending on its diameter, PM released into the atmosphere can travel high distances, has a high airborne lifetime, and may suffer various transformations [10]. Once deposited on surfaces, it can be relocated and dispersed by wind and runoff $[7,11] . \mathrm{PM}_{10}$ can contain toxic metals and organic compounds $[12,13]$. 
Vegetation, especially trees, are considered ecosystem service providers as they can reduce the pollutants level in urban areas by removing gaseous air pollution or intercepting airborne particulates $[4,14]$. A decision-making structure for the selection of the most suitable types of trees for urban areas was developed by Vlachokostas et al. [15]. Exogenous factors, such as the PM diameter and shape, exposure duration and spatial distribution, environmental variables (wind and temperature) might influence the PM deposition and metal accumulation capacity, but intrinsic features of the plant such as foliage type (deciduous, evergreen), morphology and texture of the leaves and respiration's rate determine the trees sensitivity to pollutants [11,12]. The leaves are the main sinks for metals, being more sensitive to pollution than the other plant parts (flowers, fruits, bark).

Metal pollution biomonitoring using trees is based on the changes determined by toxic metals on the morphology or composition of the tree and provides information on the contaminant's concentration and spatial distribution in the urban environment, at a relatively low cost [8]. Trees can reflect the metal pollution both in soil and atmosphere $[1,7,14,16-19]$, being able to biomonitor metal pollution over long periods, to quantify pollution parameters and to identify the spatial and temporal distribution patterns of the pollutants $[7,14]$. The metals reach plants through soil, water, and the atmosphere. In the case of trees, the metal uptake takes place in the leaves and roots systems and is controlled by the species characteristics, the concentration of metal, as well as the solubility and bioavailability of the metals. Generally, it is difficult to discriminate between the uptake routes of metals and more difficult to determine whether the uptaken metal originates from the air, water, or soil. However, in the case of trees, the metal uptake by leaves is considered the main uptake route. Tomasevic et al. reported that $\mathrm{Cu}, \mathrm{Pb}, \mathrm{Zn}$, and $\mathrm{Cd}$ in linden and horse chestnut leaves from city parks accumulate mostly following atmospheric deposition [20]. The suitability of poplar leaves to reflect the atmospheric $\mathrm{Hg}$ contamination was reported by Assad et al. [21]. Molnar et al. used common hackberry (Celtis occidentalis) and common lime (Tilia $x$ europaea) leaves to assess the level of air pollution (in urban, industrial, and rural areas of Debrecen, Hungary [9].

The poplar (Populus spp.) is one of the most effective biomonitors among the tree species due to its leaves' high sensitivity to metal pollution [22]. Poplar is a perennial deciduous tree species belonging to the Salicaceae family. It is characterized by fast growth, extensive root system, large biomass production, high resistance to water and nutrients scarcity, storms and cold weather, and also by its high metal tolerance and accumulation potential $[23,24]$. It accumulates metals through the root system and the foliage, then, by translocation, high metal contents are stored in the leaves $[25,26]$. As poplar species can easily reach $25 \mathrm{~m}$ heights and have the right stems, they are frequently used in landscaping or as green screens.

The response to environmental stressing conditions varies from plant species to plant species. High metal contents also act as stressors and trigger different protection strategies in plants. These strategies involve a complex interplay of physiological and biochemical processes, gene expression, changes in metabolism, and protein synthesis. In the case of the poplar, regulation of the metal's homeostasis by reduced uptake or increased excretion, detoxification and translocation are the main protection mechanisms [27,28].

There are more than 50 poplar varieties, but the most spread species in Europe are the black poplar (Populus nigra L.), white poplar (Populus alba L.), aspen (Populus tremula L.), and several species of poplar clones. The black poplar is one of the tree species used for air quality biomonitoring near roads or in urban areas as it is widely spread, in both urban and industrial environments, providing a large leaf area for pollutants absorption and accumulation [17]. It is more sensitive to lead stress than other poplar species [29]. Numerous studies reported the poplar's efficiency in phytoremediation and the effect of metals on the poplar's physiological processes. Regarding the poplar's biomonitoring capabilities, most of the research focuses on their use in soil pollution and only a few in air pollution $[16,17,22,23,30-37]$. 
The objective of the study was to determine the metal content of poplar leaves in Cluj-Napoca city, Romania, and to assess the potential of poplar leaves to be used for biomonitoring air pollution with particulates in urban environments. The concentration of metals in the poplar leaves from 12 sites situated in various regions of Cluj-Napoca city was correlated with the concentration of $\mathrm{PM}_{10}, \mathrm{PM}_{2.5}, \mathrm{PM}_{1}$, and total suspended particles (TSP) measured in each site. The metal content of $\mathrm{PM}_{10}$ was measured in one of the sites. Multivariate statistics were applied to identify the sources of metals in Cluj-Napoca city.

\section{Results and Discussion}

\subsection{Particulates in Air}

The TSP and $\mathrm{PM}_{10}$ concentrations in the 12 studied sites from Cluj-Napoca city varied widely from site to site, during the same day, while the $\mathrm{PM}_{2.5}$ and $\mathrm{PM}_{1}$ were, with few exceptions, comparable in all the sites (Figure 1).

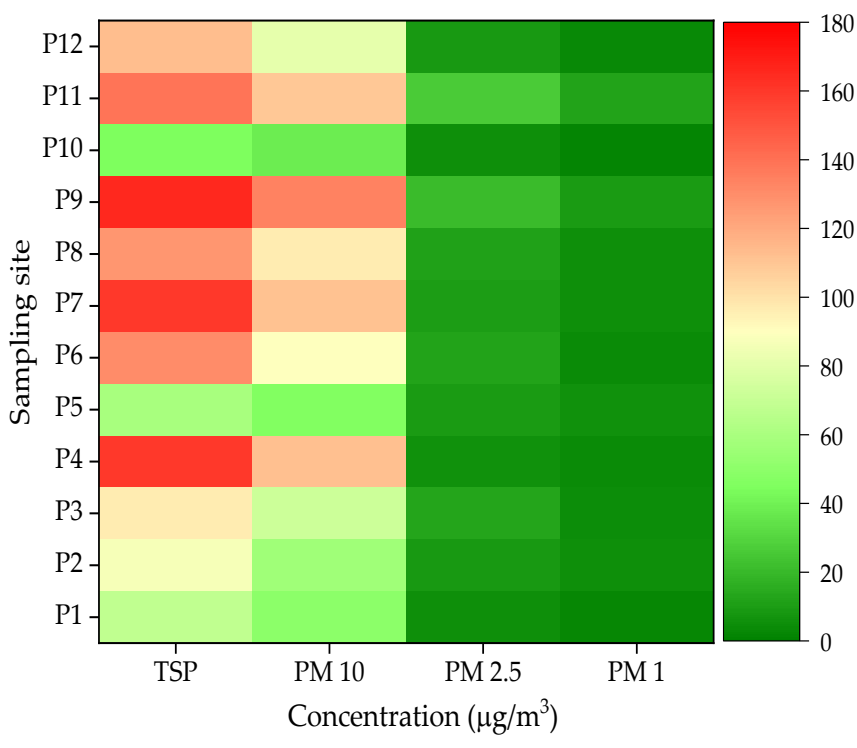

(a)

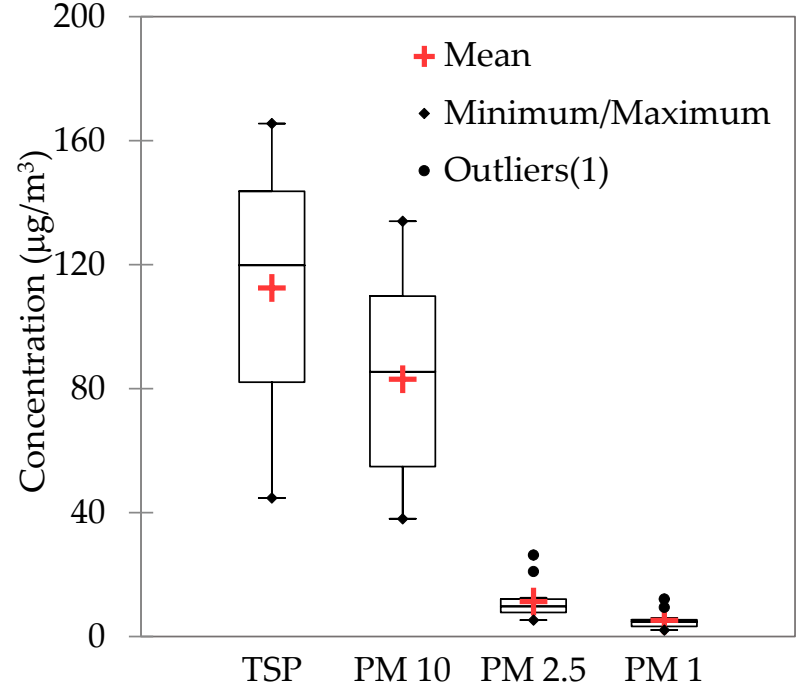

(b)

Figure 1. Total suspended particles (TSP), $\mathrm{PM}_{10}, \mathrm{PM}_{2.5}$, and $\mathrm{PM}_{1}$ in ambient air in the study sites: (a) Concentration; (b) Minimum, mean, and maximum concentration.

The highest $\mathrm{PM}_{10}$ and TSP were measured in site 9, while the highest $\mathrm{PM}_{2.5}$ and $\mathrm{PM}_{1}$ were found in site 11 , both sites being characterized by intense traffic and by the presence of construction sites. The lowest values were measured in site 10, considered a reference site, being situated in a green area with relatively low traffic. The TSP values were above the maximum admitted level $\left(150 \mu \mathrm{g} / \mathrm{m}^{3}\right)$ in 3 sites, the $\mathrm{PM}_{10}$ concentrations exceeded the daily limit value $\left(50 \mu \mathrm{g} / \mathrm{m}^{3}\right)$ in 9 of the studied sites, while the $\mathrm{PM}_{2.5}$ was below the annual limit value $\left(25 \mu \mathrm{g} / \mathrm{m}^{3}\right)$ in all sites, except one. While the average TSP $\left(113 \mu \mathrm{g} / \mathrm{m}^{3}\right)$ was below its maximum admitted threshold, the average $\mathrm{PM}_{10}\left(83 \mu \mathrm{g} / \mathrm{m}^{3}\right)$ exceeded its limit.

The daily $\mathrm{PM}_{10}$ measured during 7 consecutive days starting from the leaves sampling day with the high-volume sampler on filters also showed high $\mathrm{PM}_{10}$ values on the day of leaves sampling (day 1). However, the values sharply decreased from day $1\left(90 \mu \mathrm{g} / \mathrm{m}^{3}\right)$ to day $7\left(13 \mu \mathrm{g} / \mathrm{m}^{3}\right)$, indicating a high variability of $\mathrm{PM}_{10}$ between consecutive days in the same site (site 11). The daily limit value $\left(50 \mu \mathrm{g} / \mathrm{m}^{3}\right)$ set by the Air Quality Directive (2008/50/EC) for $\mathrm{PM}_{10}$ was only exceeded on day 1 , the measured value decreasing to $44 \mu \mathrm{g} / \mathrm{m}^{3}$ the next day [38]. The average TSP distribution among fractions (Figure 2) showed that $\mathrm{PM}_{10}$ was the major fraction (63\%), while $\mathrm{PM}_{2.5}$ and $\mathrm{PM}_{1}$ represented 5.3\% and $4.6 \%$, respectively. 


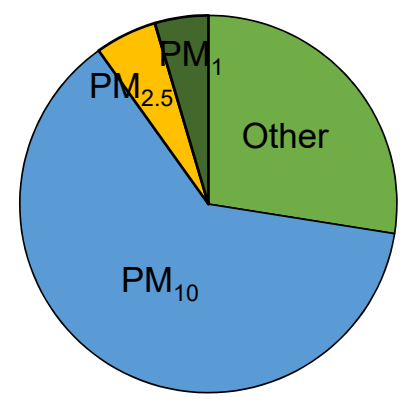

Figure 2. Average \% distribution of suspended particles fraction.

\subsection{Metal Concentration in $P M_{10}$}

The content of metals in $\mathrm{PM}_{10}$ in site 11 was low and varied slightly during the 7 monitored days. The average concentrations of metals associated to $\mathrm{PM}_{10}$ were: $\mathrm{Cd} 0.05$, $\mathrm{Co}$ 0.43, Cu 1.05, Mn 1.88, Ni 0.24, Pb 0.76, Zn 2.55, Fe 95, $\mathrm{Al} 37 \mathrm{ng} / \mathrm{m}^{3}$. None of the legislated reference thresholds set by the Directive 2008/50/EC $\left(\mathrm{Pb} 0.5 \mu \mathrm{g} / \mathrm{m}^{3}\right)$ and by the Directive 2004/107/EC ( Ni $20 \mathrm{ng} / \mathrm{m}^{3}$ and Cd $5 \mathrm{ng} / \mathrm{m}^{3}$ ) were exceeded [38,39]. The high concentrations of $\mathrm{Fe}$ and $\mathrm{Al}$ compared to the other metals indicated different sources, most probably they originated from the soil particles mobilized from roadsides by the traffic [12]. The other metals could have originated mainly from vehicles' exhaust, road dust, break and tire wear, but also from fossil fuel combustion [40]. The 9 determined metals represented less than $0.4 \%$ of the $\mathrm{PM}_{10}$, the highest percentage corresponding to $\mathrm{Al}(0.19 \%)$ and $\mathrm{Fe}$ $(0.10 \%)$, the rest of the metals accounted for only $0.07 \%$ (Figure 3 ).

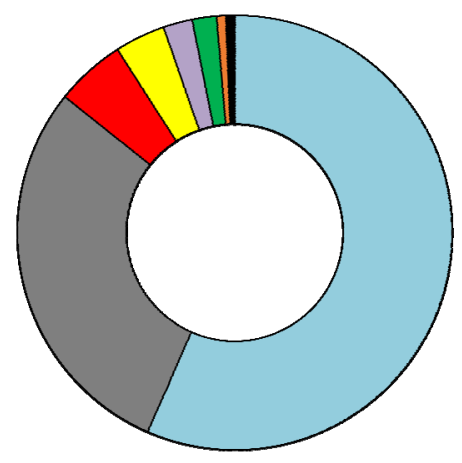

\section{$\square \mathrm{Cd} \square \mathrm{Co} \square \mathrm{Cu} \square \mathrm{Mn} \square \mathrm{Ni} \square \mathrm{Pb} \square \mathrm{Zn} \square \mathrm{Fe} \square \mathrm{AI}$}

Figure 3. Percentage distribution of metals in the $\mathrm{PM}_{10}$ fraction.

The concentrations of $\mathrm{Cd}, \mathrm{Ni}, \mathrm{Zn}$, and $\mathrm{Pb}$ were lower, while $\mathrm{Al}$ concentration was higher in Cluj-Napoca than in Ahvaz city, Iran [41]. The contents of Zn and Ni were slightly higher in Cluj-Napoca (Romania), while that of $\mathrm{Pb}, \mathrm{Cu}$, and $\mathrm{Cd}$ associated with $\mathrm{PM}_{10}$ were comparable with those reported for Varanasi (India) [42]. Our values were much lower than those obtained in the industrial city of Acerra (Italy) [43].

The results showed that the enrichment factor (EF) of $\mathrm{Co}, \mathrm{Mn}, \mathrm{Ni}$, and $\mathrm{Fe}$ in $\mathrm{PM}_{10}$ did not exceed 10, being most probably related to the earth's crust and not to anthropogenic sources. The enrichment of $\mathrm{PM}_{10}$ in $\mathrm{Pb}, \mathrm{Cu}, \mathrm{Co}, \mathrm{Zn}, \mathrm{Cd}, \mathrm{V}, \mathrm{Ni}$ was also noticed in the cities of Istanbul, Turkey, and Acerra, Italy [43-45]. $\mathrm{Cu}\left(\mathrm{EF}_{\mathrm{PM} 10}=16\right), \mathrm{Pb}\left(\mathrm{EF}_{\mathrm{PM} 10}=18\right)$, $\mathrm{Zn}\left(\mathrm{EF}_{\mathrm{PM} 10}=16\right)$ were found to be moderately enriched and of mixed origins, while $\mathrm{Cd}$ $\left(\mathrm{EF}_{\mathrm{PM} 10}=230\right)$ was highly enriched, and thus of anthropogenic origin. These results are in line with those reported by Tomasevic et al., who found that atmospheric deposition in urban parks from Belgrade was enriched with $\mathrm{Cu}, \mathrm{Pb}, \mathrm{Zn}$, and $\mathrm{Cd}$ [20]. 


\subsection{Metal Concentration in Poplar Leaves}

The metal concentrations in poplar leaves widely fluctuated (Figure 4), however, the phytotoxic level was not reached for any of the analyzed metals. $\mathrm{Fe}, \mathrm{Mn}, \mathrm{Cu}, \mathrm{Zn}$ are considered micronutrients with important roles in plant's growth but may become toxic at high concentrations, while the role of $\mathrm{Al}, \mathrm{Pb}, \mathrm{Ni}, \mathrm{Cd}$, and $\mathrm{Co}$ do not have a known role in plants' physiology and are toxic [33]. The highest variability was found for $\mathrm{Zn}$, which was also the major element in poplar leaves. Generally, $\mathrm{Zn}$ in plants ranges between 10 and $160 \mathrm{mg} / \mathrm{kg}$ and becomes toxic in the range of 70-400 mg/ $\mathrm{kg}[46,47]$. In 3 of the studied sites, the $\mathrm{Zn}$ concentration of poplar leaves was found to be higher than the normal range.

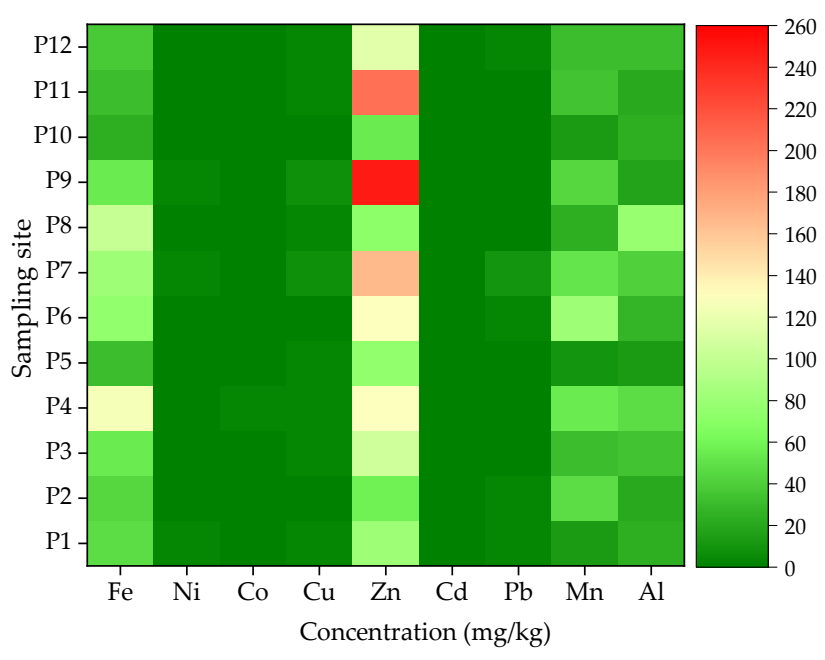

(a)

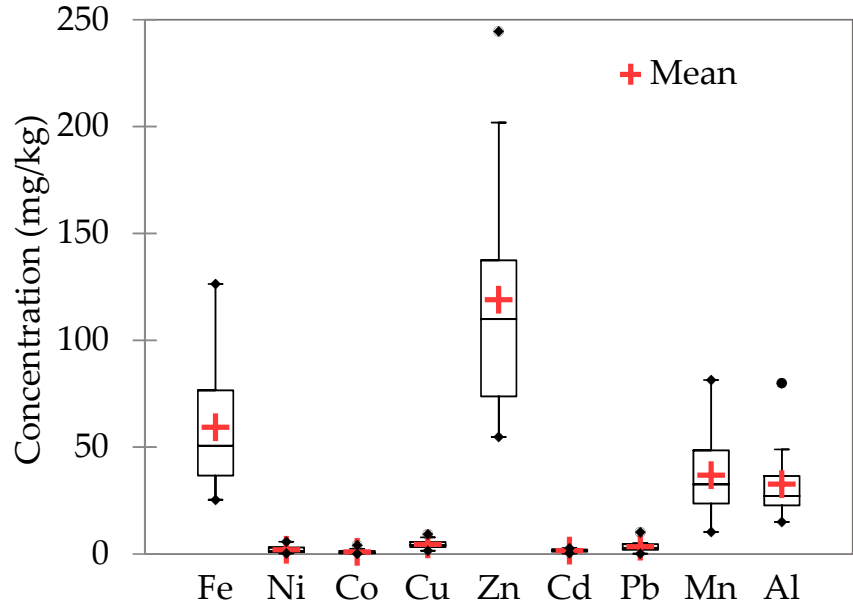

(b)

Figure 4. Concentration of metals in poplar leaves: (a) Concentration; (b) Minimum, average, and maximum.

This fact could be a consequence of the high $\mathrm{Zn}$ content $\left(2.7 \mathrm{ng} / \mathrm{m}^{3}\right)$ found to be associated with $\mathrm{PM}_{10}$ or of the poplar's ability to preferentially accumulate Zn [48]. Moreover, at low contents, $\mathrm{Zn}$ has an important role in the plant's growth, being an important constituent of several proteins and enzymes [49]. Another micronutrient for plants is $\mathrm{Cu}$, which is normally found in the range of $0.4-45.8 \mathrm{mg} / \mathrm{kg}$ in plants, becoming toxic at higher levels [47]. At all the studied sites, $\mathrm{Cu}$ in leaves had low variability, its concentration being found in the normal range, in agreement with the low $\mathrm{Cu}$ contents found to be associated with $\mathrm{PM}_{10}$. The lowest variability was found for $\mathrm{Cd}$, where the measured values ranged between $0.3-2.7 \mathrm{mg} / \mathrm{kg}$, in agreement with the low concentration of $\mathrm{Cd}\left(0.05 \mathrm{ng} / \mathrm{m}^{3}\right)$ found to be associated with $\mathrm{PM}_{10}$ and with the usual $\mathrm{Cd}$ concentration found in plants $(<10 \mathrm{mg} / \mathrm{kg})$ [20]. Similar to $\mathrm{Cu}$ and $\mathrm{Cd}, \mathrm{Pb}$ had low concentrations in the poplar leaves, being $<3 \mathrm{mg} / \mathrm{kg}$ in the majority of the samples, far below the toxic levels $(>20 \mathrm{mg} / \mathrm{kg})$ [47]. A possible cause for the low $\mathrm{Pb}$ content in leaves could originate from the fact that the $\mathrm{Pb}$ uptake occurs through the root system and not by particulates deposition. Moreover, $\mathrm{Pb}$ translocation to the aerial parts is usually low [33].

$\mathrm{Fe}$ and $\mathrm{Al}$ were found in lower concentrations than $\mathrm{Zn}$, but in higher concentrations than the other studied metals. These elements generally come from soil particles dispersed by winds and traffic or from fossil fuel burning, followed by a subsequent deposition on the leaves $[40,50]$. The concentrations of $\mathrm{Fe}, \mathrm{Al}, \mathrm{Mn}$, and $\mathrm{Co}$ were also lower than the typical range found in plants: $640-2486,200-1000,15-100$, and $0.1-10 \mathrm{mg} / \mathrm{kg}$, respectively [47]. Of these metals, Fe and $\mathrm{Mn}$ are considered essential microelements for plant growth, while Co has no proven physiological function [47]. According to Hajar et al., the typical concentration range for plants is $0.1-3.7 \mathrm{mg} / \mathrm{kg}$ [47]. The average Ni content in P. nigra leaves $(2 \mathrm{mg} / \mathrm{kg})$ obtained in the present study was within the typical concentration range, except for 3 of the sites, where it was slightly higher. The concentration of metals in poplar 
leaves collected from the reference site (site 10) was the lowest for $\mathrm{Fe}, \mathrm{Ni}$, and $\mathrm{Zn}$, but in the case of the other elements, lower values were found in some of the other sites. The concentrations of $\mathrm{Cu}, \mathrm{Ni}, \mathrm{Pb}$ were comparable, while those of $\mathrm{Zn}$ and $\mathrm{Cd}$ were slightly higher than those found in poplar leaves collected in Navodari, Romania [32]. Similar contents of $\mathrm{Cd}, \mathrm{Ni}, \mathrm{Cu}$, and $\mathrm{Pb}$ and much higher values of $\mathrm{Mn}, \mathrm{Fe}$, and $\mathrm{Zn}$ were reported in white poplar leaves collected in a spill that affected the mining area of the Guadiamar basin, Spain [33]. The concentrations obtained in our study were higher for $\mathrm{Zn}, \mathrm{Cu}$, and $\mathrm{Cd}$, and comparable for $\mathrm{Pb}$ with those determined in the leaves of Populus deltoides in Yazd city, Iran [46]. The average Zn content was 4 times lower than the concentration determined in black poplar leaves from the heavily industrialized Ust-Kamenogorsk city in Kazakhstan [22]. In comparison with P. nigra, the leaves of local pine trees, Pinus eldarica, from Yazd city, Iran, accumulated Fe in high concentrations (345 mg/kg) and Cd in low concentrations $(0.73 \mathrm{mg} / \mathrm{kg})$. Cu concentrations were in the normal range $(30 \mathrm{mg} / \mathrm{kg})$, except for one sampling site [51]. In a study carried out by Norouzi et al. [52], Platanus orientalis leaves were used as a bioindicator of atmospheric pollution, by determining the concentrations of $\mathrm{Cu}, \mathrm{Fe}, \mathrm{Mn}, \mathrm{Ni}, \mathrm{Pb}$, and $\mathrm{Zn}$. Their results indicated significant levels of $\mathrm{Fe}$ and $\mathrm{Mn}$, followed by $\mathrm{Zn}, \mathrm{Cu}$, and $\mathrm{Ni}$, and a low level of $\mathrm{Pb}$ (Table 1).

Table 1. Concentration of heavy metals in the leaves of different species.

\begin{tabular}{|c|c|c|c|c|c|c|c|c|c|c|}
\hline \multirow{2}{*}{ Species } & \multicolumn{9}{|c|}{ Heavy Metals (mg/kg) } & \multirow{2}{*}{ Reference } \\
\hline & $C d$ & Co & $C u$ & $M n$ & $N i$ & $P b$ & $Z n$ & $\mathrm{Fe}$ & $A l$ & \\
\hline Populus nigra L. & 1.60 & 1.10 & 4.60 & 36.9 & 2.00 & 3.50 & 119 & 59.4 & 32.7 & Present study \\
\hline Pinus eldarica & 0.74 & - & 5.59 & - & - & 2.99 & 26.1 & 345 & - & Miri et al. 2017 [51] \\
\hline Platanus orientalis L. & - & - & 15.1 & - & - & 1.13 & 35.0 & 404 & - & Norouzi et al. 2015 [52] \\
\hline Ulmus umbraculifera & 0.08 & - & 7.97 & - & 2.76 & 1.55 & 22.5 & - & - & Hajizadeh et al. 2019 [53] \\
\hline Juglans regia & 0.03 & - & 7.08 & - & 2.17 & 1.63 & 22.4 & - & - & Hajizadeh et al. 2019 [53] \\
\hline Vitis vinifera & 0.03 & - & 5.11 & - & 2.10 & 1.24 & 24.8 & - & - & Hajizadeh et al. 2019 [53] \\
\hline Taraxacum officinale & 1.29 & - & 10.1 & 24.8 & - & 28.1 & 180 & 159 & - & Nadgorska-Socha et al. 2017 [54] \\
\hline Plantago lanceolata & 1.55 & - & 5.85 & 47.1 & - & 25.4 & 97.6 & 299 & - & Nadgorska-Socha et al. 2017 [54] \\
\hline Betula pendula & 0.72 & - & 2.94 & 63.3 & - & 16.0 & 389 & 260 & - & Nadgorska-Socha et al. 2017 [54] \\
\hline Robinia pseudoacacia & 0.65 & - & 1.78 & 25.2 & - & 11.1 & 52.7 & 192 & - & Nadgorska-Socha et al. 2017 [54] \\
\hline
\end{tabular}

The total metal content in poplar leaves raised with the increase of $\mathrm{PM}_{10}$ and TSP (Figure 5), although a linear relationship was not observed. The lowest metal contents were found in site 10, considered as a reference site for Cluj-Napoca. The highest total metal content in leaves was found in sites 4, 7, and 9, together with the highest levels of TSP and $\mathrm{PM}_{10}$. These sites are characterized by intense traffic and proximity to the tram or train lines. The average total metals content in poplar leaves was $46 \%$ for $\mathrm{Zn}, 23 \%$ for $\mathrm{Fe}$, $14 \%$ for $\mathrm{Mn}$, and $12 \%$ for Al. Although metals emitted by urban pollution sources can easily bind to airborne particulates and then can be deposited on the leaves' surfaces, their accumulation in the poplar leaves also depends on the meteorological conditions (wind, rain) and the individual tree physiology. The high concentrations of $\mathrm{Zn}$ found in the leaves suggest that poplar is a good accumulator and can be used not only for biomonitoring but also as a natural barrier, useful for contaminants retention in vulnerable areas. Our findings are in agreement with those of Liu et al., who reported the suitability of Populus tomentosa for the reduction of $\mathrm{Zn}$ from airborne dust [48]. Similar to other tree species, $\mathrm{Zn}$ is an essential element for poplar, but in excess, it may block the absorption of other essential metals $(\mathrm{P}$, $\mathrm{Mg}, \mathrm{Mn}$ ) and trigger toxic effects such as growth inhibition and leaf chlorosis. These effects were more visible in the early development stages of poplar than in mature plants, where the regulator mechanisms were fully developed. The homeostasis of $\mathrm{Zn}$ was assured by the active metabolism in roots and leaves. The $\mathrm{Zn}$ transport and accumulation were regulated by an 1186-amino acid P-type heavy metal ATPase (HMA4) while Zn detoxification was regulated by phytochelatins and metallothionines [27]. 


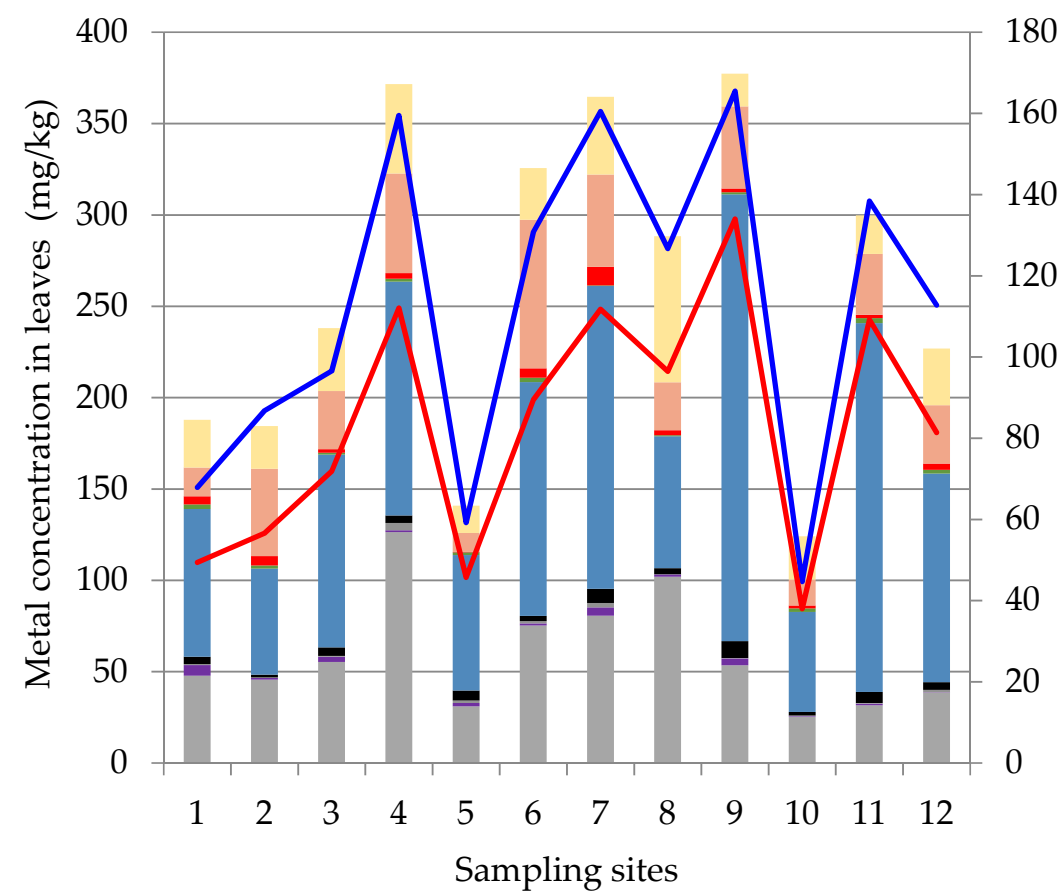

180

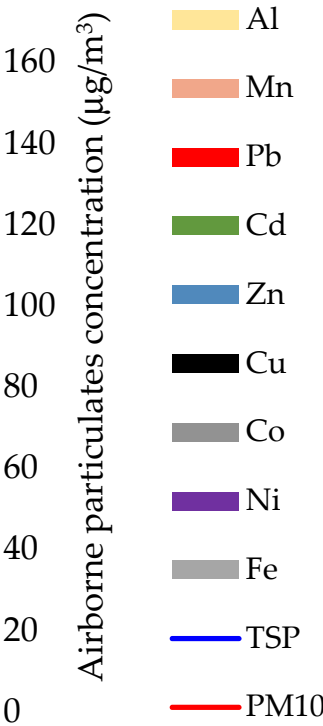

Figure 5. Concentration of metals in poplar leaves $(\mathrm{mg} / \mathrm{kg})$ and of $\mathrm{TSP}$ and $\mathrm{PM}_{10}\left(\mu \mathrm{g} / \mathrm{m}^{3}\right)$ in air.

The metal accumulation index (MAI) for poplar species from Cluj-Napoca was 1.7, showing that poplar is a moderate metal accumulator. The obtained MAI value could be explained, on the one hand, by the low metal content in the air and, on the other hand by the tolerance mechanisms developed by poplar [26]. The MAI for black poplar in this study was lower than for Populous deltoids (MAI = 6.6) and Populus tomentosa (MAI = 7.1) $[46,55]$.

The metal accumulation factor (MAF) calculated as the ratio between the metal content in the poplar leaves from the study site and from a reference site (site 10 in our study) showed that metal accumulation occurred in each site, for all the studied metals, except for $\mathrm{Cd}$. Average MAF > 2 were obtained for $\mathrm{Zn}$ (2.3), $\mathrm{Pb}$ (2.4), $\mathrm{Fe}$ (2.5), $\mathrm{Cu}$ (2.5), Mn (2.8), Co (3.8), and $\mathrm{Ni}$ (6.8). The lack of $\mathrm{Cd}$ accumulation in all sites could be explained by the high content of $\mathrm{Cd}$ found in the poplar leaves from the reference site and by the low intrinsic ability of poplar to bioaccumulate $\mathrm{Cd}$ compared to other metals. This fact could suggest a wider spread of $\mathrm{Cd}$ pollution than expected, that also reached green areas situated far from the intense traffic or a possible transfer from the soil.

Our data indicated no enrichment for $\mathrm{Cd}$, minor enrichments for $\mathrm{Fe}, \mathrm{Pb}, \mathrm{Cu}, \mathrm{Co}, \mathrm{Zn}$, $\mathrm{Mn}$, and a moderate enrichment for Ni. The spatial distribution of both MAF and $\mathrm{EF}_{\text {poplar }}$ varied from metal to metal suggesting the existence of local, unidentified pollution sources that may overlap with the pollution sources related to traffic.

\subsection{Metal Sources}

The principal component analysis (PCA) revealed that 4 principal components (PC's) with eigenvalues higher than 1 explain $87 \%$ of the system variability (Table 2). The PC1 explains $38.3 \%$ of the variability and is related to the positive loadings of $\mathrm{Cu}, \mathrm{Zn}$, and particulates and could be associated with air pollution, most probably from traffic and combustion processes, as $\mathrm{Zn}$ is an indicator of tire and brake wear and waste burning [56]. PC2 explains $25.9 \%$ of the variability and includes $\mathrm{Fe}, \mathrm{Co}, \mathrm{Pb}, \mathrm{Mn}, \mathrm{TSP}$ and could be associated with air pollution with coarse particles due to road dust resuspension. The influence of these two PC's is confirmed by the high enrichment of $\mathrm{Cu}, \mathrm{Pb}$, and $\mathrm{Zn}$ in $\mathrm{PM}_{10}$. PC 3 explains $12.3 \%$ of the variability and includes $\mathrm{Ni}, \mathrm{Cu}$, and $\mathrm{Pb}$ and could be attributed to soil pollution. The PC4 explains $10.2 \%$ of the variability and groups the Fe and $\mathrm{Al}$ with positive loading and could represent natural sources, such as earth crust erosion. 
Table 2. Factor loadings of $P C^{\prime}$ s after varimax rotation.

\begin{tabular}{ccccc}
\hline & PC1 & PC2 & PC3 & PC4 \\
\hline Eigenvalue & 4.9 & 3.4 & 1.6 & 1.3 \\
Variability (\%) & 38.3 & 25.9 & 12.3 & 10.2 \\
Cumulative (\%) & 38.3 & 64.2 & 76.5 & 86.7 \\
\hline $\mathrm{Fe}$ & -0.002 & $\mathbf{0 . 6 2 0}$ & -0.070 & $\mathbf{0 . 7 2 3}$ \\
$\mathrm{Ni}$ & 0.082 & -0.006 & $\mathbf{0 . 9 1 8}$ & 0.005 \\
$\mathrm{Co}$ & -0.132 & $\mathbf{0 . 7 3 6}$ & 0.071 & 0.205 \\
$\mathrm{Cu}$ & $\mathbf{0 . 7 6 2}$ & 0.006 & $\mathbf{0 . 5 6 8}$ & 0.079 \\
$\mathrm{Zn}$ & $\mathbf{0 . 9 1 5}$ & 0.261 & 0.213 & -0.090 \\
$\mathrm{Cd}$ & -0.072 & 0.027 & -0.416 & $-\mathbf{0 . 7 7 6}$ \\
$\mathrm{Pb}$ & -0.105 & $\mathbf{0 . 6 4 9}$ & $\mathbf{0 . 5 1 5}$ & 0.081 \\
$\mathrm{Mn}$ & 0.265 & $\mathbf{0 . 8 5 8}$ & -0.152 & -0.030 \\
$\mathrm{Al}$ & -0.122 & 0.154 & -0.153 & $\mathbf{0 . 9 1 3}$ \\
$\mathrm{TSP}$ & $\mathbf{0 . 7 0 0}$ & $\mathbf{0 . 6 0 2}$ & 0.048 & 0.364 \\
$\mathrm{PM}_{10}$ & $\mathbf{0 . 8 0 0}$ & 0.455 & 0.042 & 0.357 \\
$\mathrm{PM}_{2.5}$ & $\mathbf{0 . 9 4 3}$ & -0.182 & -0.115 & -0.133 \\
$\mathrm{PM}$ & $\mathbf{0 . 9 1 3}$ & -0.202 & -0.052 & -0.147 \\
\hline
\end{tabular}

${ }^{1}$ Bold data represent the elements with correlation values higher than 0.5 .

Wilks [57] explains the PCA technique as a tool for lowering the dimensionality of a model (data compression) by grouping the initial variables into eigenvectors (linearly independent dimensions). The biplot is a graphical method for representing these dimensions two by two, allowing to visualize the influence (projections) of all the initial variables on the eigenvectors. A biplot was used to simultaneously represent the observations from the 12 sampling sites and the variables: the $\mathrm{Fe}, \mathrm{Ni}, \mathrm{Co}, \mathrm{Cu}, \mathrm{Zn}, \mathrm{Cd}, \mathrm{Pb}, \mathrm{Mn}, \mathrm{Al}$ content in poplar leaves and $\mathrm{PM}_{1}, \mathrm{PM}_{2.5}$, and $\mathrm{PM}_{10}$ concentrations and TSP in the air. The sampling sites are grouped according to Figure 6 into 3 groups: G1 contains sites 9 and 11 situated in an area with a high concentration of particulates where the poplar leaves had high $\mathrm{Cu}$ and $\mathrm{Zn}$ and low $\mathrm{Mn}, \mathrm{Pb}, \mathrm{Fe}, \mathrm{Co}$ concentrations, situated under the influence of intense vehicular traffic and construction sites.

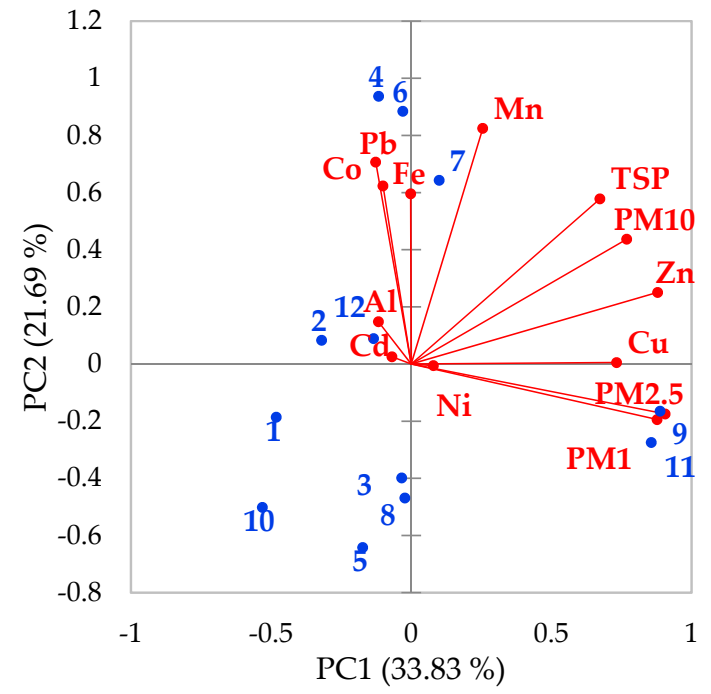

(a)

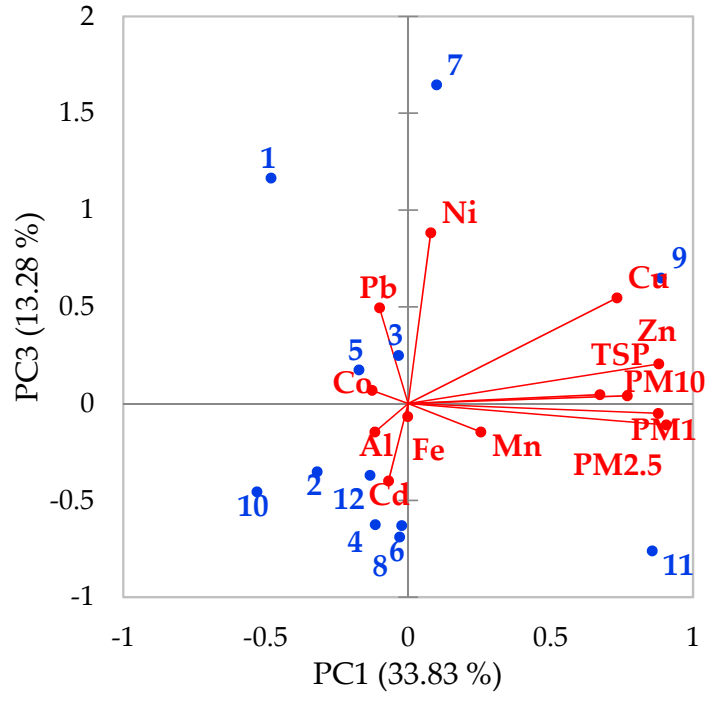

(b)

Figure 6. PCA biplots representing both observations (sampling sites) and variables (metal content in poplar leaves and PM concentration in air): (a) PC1-PC2, (b) PC1-PC3.

G2 groups at sites 4, 6, 7, that had low $\mathrm{PM}_{1}$ and $\mathrm{PM}_{2.5}$, but high TSP $\mathrm{PM}_{10}$ and Fe, $\mathrm{Co}, \mathrm{Pb}, \mathrm{Mn}$ in poplar leaves were impacted by dust resuspension. G3, which contains the other sites, was characterized by low levels of air particulates and low levels of metals in 
the poplar leaves. These sites are situated at higher distances from the roads with intense traffic. Our data indicate that poplar is a good passive biomonitor of the spatial distribution of metal pollution and may be used in further urban greening programs for biomonitoring, as well as for air pollution reduction purposes.

\section{Materials and Methods}

\subsection{Sampling and On-Site Measurements}

Situated in the north-western part of Romania, Cluj-Napoca city is one of the most populated cities in the country, with around 420,000 inhabitants in the metropolitan area. The city is located in the Somes Mic river valley (average altitude $363 \mathrm{~m}$ ) and is bordered in the west by the Hoia hill $(507 \mathrm{~m})$ and in the south by the Feleacu hill $(759 \mathrm{~m})$. ClujNapoca has a continental climate with warm, dry summers and cold winters. The average annual temperature is $8.2{ }^{\circ} \mathrm{C}$ and the average precipitation is $557 \mathrm{~mm}$. The dominant wind directions are NW ( 15\%), NE ( 12\%), W ( 10\%), and SW $(\sim 10 \%)$. The temperatures are slightly lower in the parts of the city situated along the Somes Mic river than in the rest of the city, as thermal inversions are more frequent along the river. In the city, there are registered around 1200 buses, 150,000 passenger cars, 25,000 freight vehicles, and 8000 mopeds and motorcycles. The city has low industrial activity, the main industrial polluting sources being progressively replaced by services and IT companies, in the last decades. The city is short of green areas and parks, the land use nearby the city being changed from agricultural land into residential locations by the intense urban development. The main metal pollution sources are mostly related to traffic, construction sites, urban runoff, residential heating, and municipal landfilling [58].

Poplar is a frequent tree species in Romania, planted mostly at the beginning of the 19th century, mainly along roads and railroads for landscaping purposes. Currently, most of these trees were cut, partly due to their aging and partly as a consequence of the city's expansion, road enlargement, and rehabilitation. Nowadays, in Cluj-Napoca, poplar is mainly found in small green areas along the Somes Mic River bank, small roads, or buildings.

In September 2018, after 10 days without precipitations, black poplar (Populus nigra L.) leaves were collected from 12 sites situated in Cluj-Napoca city, Romania (Figure 7).

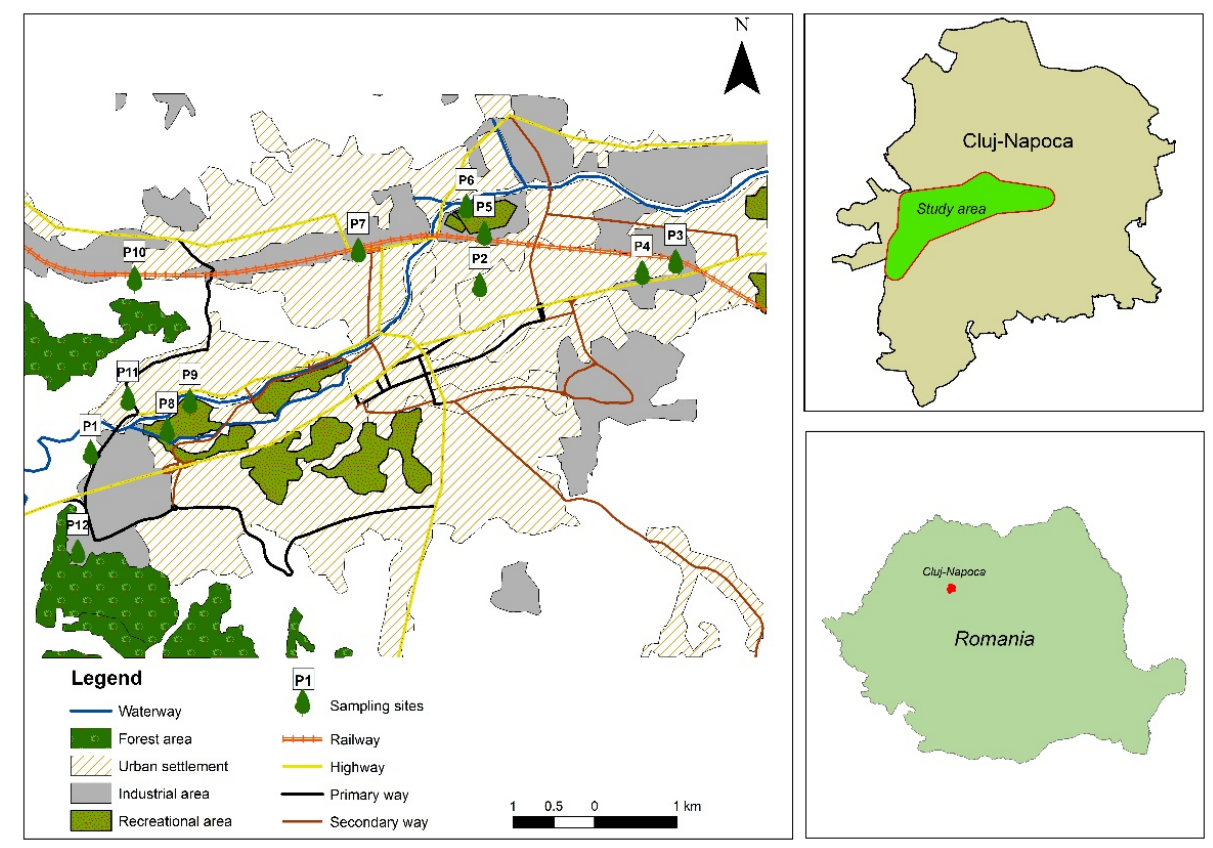

Figure 7. Map of study area and sampling points. 
The concentrations of metals in poplar leaves increase along the vegetation period, being higher at senescence than at emergence [20,21]. Site 10 was considered a reference site as it is situated far from roads with high traffic in a green area. Sites 4, 6, 7, 9, and 11 are characterized by intense traffic, sites $1,2,3,5$, and 8 by moderate traffic, while sites 10 and 12 by low traffic. The sampled poplars were of similar height and similar age and did not show any illness or damage. In each site, 10-20 mature leaves from 3 branches from different sides of the outer canopy of a single tree were collected from a height of 2-2.5 m. Only leaves that were not affected by bird falls, insect infection, chlorosis, or necrosis were selected. The leaves were separated from the branches using a Teflon coated scissor and transported into the lab in paper bags.

In the same sites, instantaneous values of the TSP, particles with diameter less than $10 \mu \mathrm{m}\left(\mathrm{PM}_{10}\right), 2.5 \mu \mathrm{m}\left(\mathrm{PM}_{2.5}\right)$, and $1 \mu \mathrm{m}\left(\mathrm{PM}_{1}\right)$ were measured in the ambient air using an Aerocet 831 handheld laser scattering particle counter (Met One Instruments, Washington, US). At each site, 25 consecutive measurements with the duration of 1 minute were performed and the results are reported as the average value. The Aerocet 831 counts and sizes particles in 7 different size ranges and then uses an algorithm to convert count data to mass measurements $\left(\mu \mathrm{g} / \mathrm{m}^{3}\right)$. It allows measurements in the $0-1000 \mu \mathrm{g} / \mathrm{m}^{3}$ concentration range with a resolution of $0.1 \mu \mathrm{g} / \mathrm{m}^{3}$ and accuracy of $\pm 10 \%$. The precision and accuracy of direct reading particle-counters, such as Aerocet 831, were studied in detail by Borghi et al. [59]. The Aerocet 831 was successfully used in the evaluation of exposure levels to various airborne pollutants in Milan, Italy [60], to measure the concentrations of particulate matter around heavy traffic in Ogbomoso, Nigeria [61] and to assess the impact of various traffic congestion on Cupressus arizonica and Pinus nigra seed germination [62].

In sampling site 11, during a 7 day period, the $\mathrm{PM}_{10}$ was collected for $24 \mathrm{~h}$ on $150 \mathrm{~mm}$ diameter micro-glass fiber filters of MG227/1/60 grade (Sartorius, Gottingen, Germany) preconditioned $\left(20 \pm 2{ }^{\circ} \mathrm{C}\right.$ and $45 \pm 5 \%$ relative humidity) at a constant weight using a DHA-80 high volume sampler (Digitel Elektronik $\mathrm{GmbH}$, Burs, Austria), with a flow rate of $500 \mathrm{~L} / \mathrm{min}$, equipped with an automatic sample charger. Unexposed filters were used as field and lab-blanks to control contamination during transportation and handling.

\subsection{Sample Preparation and Analysis}

The content of $\mathrm{PM}_{10}$ was determined gravimetrically, using a Cubis MSA125P analytical balance (Sartorius, Goettingen, Germany) after the filters conditioning to constant weight in a climatic chamber with constant relative humidity (45 $\pm 5 \%$ ) and temperature $\left(20 \pm 2{ }^{\circ} \mathrm{C}\right)$ for $72 \mathrm{~h}$.

The poplar leaves were washed with distilled water, blotted to dryness, freeze-dried at $-40{ }^{\circ} \mathrm{C}$ and -25 psi using a FreeZone 2.5 Liter Benchtop freeze dry system (Labconco, KS, USA) and powdered with a GM200 Grindomix Knife Mill (Retsch GMBH, Haan, Germany).

Amounts of $1 \mathrm{~g}$ of leaf powder were digested with $5 \mathrm{~mL}$ of $65 \% \mathrm{HNO}_{3}$ and $2 \mathrm{~mL}$ of $30 \% \mathrm{H}_{2} \mathrm{O}_{2}$ in a closed polytetrafluoroethylene vessel MWS-3+ microwave digestion system (Berghof, Eningen, Germany). The digested samples were filtered and diluted to $25 \mathrm{~mL}$ with ultrapure water (Elga PURELAB flex, Veolia, Wycombe, UK). The filters loaded with $\mathrm{PM}_{10}$ were digested in an open vessel with $28 \mathrm{~mL}$ aqua regia $(21 \mathrm{~mL}$ of $37 \%$ $\mathrm{HCl}$ and $7 \mathrm{~mL}$ of $65 \% \mathrm{HNO}_{3}$ ), at room temperature for $4 \mathrm{~h}$ and at reflux conditions for $2 \mathrm{~h}$. After cooling to room temperature, the slurry was filtered and diluted to $25 \mathrm{~mL}$ with ultrapure water. The contents of $\mathrm{Cu}, \mathrm{Pb}, \mathrm{Zn}, \mathrm{Cd}, \mathrm{Co}, \mathrm{Ni}, \mathrm{Fe}, \mathrm{Mn}$, and $\mathrm{Al}$ in the digested samples were determined using an ELAN DRC II spectrometer (Perkin Elmer, Waltham, MA, United States). The calibration curves were prepared using $10 \mathrm{mg} / \mathrm{L}$ multielement standard solutions (Perkin Elmer, Waltham, MA, USA) ranging between 0-100 $\mu \mathrm{g} / \mathrm{L}$. Calibration standards, procedural blank measurements, and duplicate samples were used for the quality assurance of results. The accuracy of metal determination was checked by analyzing the NIST-SRM 1515 Apple leaves reference material. The mean recoveries for the determination of metals in CRMs ranged between 94\% and 105\%. The use of ICP-MS for the measurement of metal content in plants was reported also for poplar leaves, cinnamon 
tree leaves, and pine needles $[16,33,63,64]$. The metal concentrations were measured in duplicate and the results were reported as average.

\subsection{Data Analysis}

In order to identify the contribution of anthropogenic sources to the level of metals found in $\mathrm{PM}_{10}$, the enrichment factor $\left(\mathrm{EF}_{\mathrm{PM} 10}\right)$ was calculated for each metal according to Equation (1), considering $\mathrm{Al}$ as a reference element, due to its minor contribution to the atmospheric pollution level [41]. Values of $\mathrm{EF}_{\mathrm{PM} 10}<10$ indicated that the metals were not enriched and had a crustal origin, $10<\mathrm{EF}_{\mathrm{PM} 10}>100$ indicated a moderate enrichment and a mixed origin of the elements, while $\mathrm{EF}_{\mathrm{PM} 10}>100$ indicated a high enrichment through anthropogenic sources [20,43-45].

$$
\mathrm{EF}_{\mathrm{PM}_{10}}=\frac{\left(\frac{\mathrm{C}_{\mathrm{M}}}{\mathrm{C}_{\mathrm{Al}}}\right)_{\mathrm{PM}_{10}}}{\left(\frac{\mathrm{C}_{\mathrm{M}}}{\mathrm{C}_{\mathrm{Al}}}\right)_{\mathrm{UCC}}}
$$

where: $\left(\mathrm{C}_{\mathrm{M}} / \mathrm{C}_{\mathrm{Al}}\right)_{\mathrm{PM} 10}$ is the ratio between the metal and $\mathrm{Al}$ concentration in $\mathrm{PM}_{10} ;\left(\mathrm{C}_{\mathrm{M}} / \mathrm{C}_{\mathrm{Al}}\right) \mathrm{UCC}$ is the ratio between the metal and $\mathrm{Al}$ concentration in the upper continental crust given by Rudnick and Gao [65].

To assess the ability of the poplar to simultaneously accumulate several metals, the metal accumulation index (MAI) was calculated according to Equation (2) [55].

$$
\mathrm{MAI}=\frac{1}{\mathrm{~N}} \sum_{\mathrm{j}=1}^{\mathrm{N}} \mathrm{I}_{\mathrm{j}}
$$

where: $\mathrm{N}$ is the number of metals ( 9 in our study); $\mathrm{Ij}$ is the ratio between the mean concentration of each metal and its standard deviation.

The enrichment factor of metals in poplar leaves $\left(\mathrm{EF}_{\mathrm{poplar}}\right)$ was calculated as the ratio of metal contents normalized to $\mathrm{Al}$ in the poplar leaves from the study and reference site according to Equation (3). $\mathrm{EF}_{\text {poplar }}<1$ indicated no enrichment, $\mathrm{EF}_{\text {poplar }}<3$ indicated minor enrichment, $\mathrm{EF}_{\text {poplar }}<10$ showed moderate enrichment, and $\mathrm{EF}_{\text {poplar }}>10$ suggested severe enrichment [40].

$$
\mathrm{EF}_{\text {poplar }}=\frac{\left(\frac{\mathrm{C}_{\mathrm{M}}}{\mathrm{C}_{\mathrm{Al}}}\right)_{\text {study site }}}{\left(\frac{\mathrm{C}_{\mathrm{M}}}{\mathrm{C}_{\mathrm{Al}}}\right)_{\text {reference site }}},
$$

where: $\left(\mathrm{C}_{\mathrm{M}} / \mathrm{C}_{\mathrm{Al}}\right)$ is the ratio between the metal and $\mathrm{Al}$ concentration in poplar leaves.

The possible metal sources in the air were investigated using PCA. This method allows the reduction of the dataset into several independent components named PC's. The varimax rotation approach on PC's with eigenvalues higher than 1 was applied on standardized data using the XLSTAT (Addinsoft) Microsoft Excel add-on software. PCA analysis was previously used for metal sources identification in Pinus eldarica leaves and for the assessment of pollution trends in Adana urban area, Tukey, using the concentration of trace elements in the leaf samples collected from 75 trees $[51,66]$.

\section{Conclusions}

Black poplar (Populus nigra L.) was used for the passive biomonitoring of air pollution with particulates in Cluj-Napoca city, Romania. High variability of the particulates and instantaneous $\mathrm{PM}_{10}$ density was found between the sampling sites, with values ranging between $38-134 \mu \mathrm{g} / \mathrm{m}^{3}$. $\mathrm{PM}_{10}$ was the major fraction of particulates $(63 \%)$ in every site. The daily $\mathrm{PM}_{10}$ values ranged between $13-90 \mu \mathrm{g} / \mathrm{m}^{3}$ and contained only low levels of metals $(<0.4 \%)$. The most abundant metals in $\mathrm{PM}_{10}$ were $\mathrm{Al}$ and $\mathrm{Fe}$, followed by $\mathrm{Zn}, \mathrm{Mn}$, $\mathrm{Cu}$, and $\mathrm{Pb}$. The moderate enrichment factor of $\mathrm{Cu}, \mathrm{Pb}$, and $\mathrm{Zn}$ and the high enrichment factor of $\mathrm{Cd}$ in $\mathrm{PM}_{10}$ indicated that $\mathrm{Cd}$ is of anthropogenic origin, while the other metals have both natural and anthropogenic origin. In the poplar leaves samples, $\mathrm{Zn}$ was the 
major metal, followed by $\mathrm{Fe}, \mathrm{Mn}, \mathrm{Al}, \mathrm{Pb}, \mathrm{Cu}, \mathrm{Ni}, \mathrm{Co}$, and $\mathrm{Cd}$. The sum of metal contents in leaves increased with the increase of $\mathrm{PM}_{10}$. Metal accumulation in poplar leaves in measurable concentrations was observed in each site, for all studied metals, except for $\mathrm{Cd}$, suggesting that poplar leaves are suitable to be used for the biomonitoring of pollution. The main identified anthropogenic sources of metals in the poplar leaves were: traffic and waste burning $(\mathrm{Cu}, \mathrm{Zn})$, road dust resuspension $(\mathrm{Fe}, \mathrm{Pb}, \mathrm{Mn}, \mathrm{Co})$, and soil contamination $(\mathrm{Pb}, \mathrm{Cu}, \mathrm{Ni})$.

Author Contributions: Conceptualization, L.L. and A.O.; methodology, L.L. and E.K.; formal analysis, A.I.T. and E.A.L.; investigation, L.L., E.K., O.C., A.I.T. and V.B.-F.; writing-original draft preparation, L.L., E.K., E.A.L.; writing-review and editing, A.O., A.I.T. and O.C.; visualization, L.L.; supervision A.O. and O.C. All authors have read and agreed to the published version of the manuscript.

Funding: This research was funded by the Romanian National Core Program, project no. PN 19-18.01.01 (contract no. 18N/08.02.2019).

Conflicts of Interest: The authors declare no conflict of interest. The funder had no role in the design of the study; in the collection, analyses, or interpretation of data; in the writing of the manuscript, or in the decision to publish the results.

\section{References}

1. Tangahu, B.V.; Abdullahh, S.R.S.; Basri, H.; Idris, M.; Anuar, N.; Mukhlisin, M. A review on heavy metals (As, Pb, and Hg) uptake by plants through phytoremediation. Int. J. Chem. Eng. 2011, 2011, 1-31. [CrossRef]

2. Hoaghia, M.A.; Levei, E.A.; Cadar, O.; Senila, M.; Hognogi, G.G. Assessment of metal contamination and ecological risk in urban soils situated near a metallurgical complex. Environ. Eng. Manag. J. 2017, 16, 1623-1630. [CrossRef]

3. Miclean, M.; Cadar, O.; Levei, E.A.; Roman, R.; Ozunu, A.; Levei, L. Metal ( $\mathrm{Pb}, \mathrm{Cu}, \mathrm{Cd}$, and $\mathrm{Zn}$ ) transfer along food chain and health risk assessment through raw milk consumption from free-range cows. Int. J. Environ. Res. Public Health 2019, 16, 4064. [CrossRef]

4. Nowak, D.J.; Hirabayashi, S.; Doyle, M.; McGovern, M.; Pasher, J. Air pollution removal by urban forests in Canada and its effect on air quality and human health. Urban For. Urban Green. 2018, 29, 40-48. [CrossRef]

5. Polichetti, G.; Cocco, S.; Spinali, A.; Trimarco, V.; Nunziata, A. Effects of particulate matter $\left(\mathrm{PM}_{10}, \mathrm{PM}_{2.5}\right.$ and $\left.\mathrm{PM}_{1}\right)$ on the cardiovascular system. Toxicology 2009, 261, 1-8. [CrossRef] [PubMed]

6. Schraufnagel, D.E. The health effects of ultrafine particles. Exp. Mol. Med. 2020, 52, 311-317. [CrossRef] [PubMed]

7. Gajbhiye, T.; Pandey, S.K.; Lee, S.S.; Kim, K. Size fractionated phytomonitoring of airborne particulate matter (PM) and speciation of PM bound toxic metals pollution through Calotropis procera in an urban environment. Ecol. Indic. 2019, 104, 32-40. [CrossRef]

8. Moreira, T.C.L.; de Oliveira, C.R.; Amato, L.F.L.; Kang, C.M.; Saldiva, P.H.N.; Saiki, M. Intra-urban biomonitoring: Source apportionment using tree barks to identify air pollution sources. Environ. Int. 2016, 91, 271-275. [CrossRef]

9. Molnar, V.E.; Tozser, D.; Szabo, S.; Tothmeresz, B.; Simon, E. Use of leaves as bioindicator to assess air pollution based on composite proxy measure (APTI), dust amount and elemental concentration of metals. Plants 2020, 9, 1743. [CrossRef] [PubMed]

10. Rucandio, M.I.; Petit-Domínguez, M.D.; Fidalgo-Hijano, C.; García-Giménez, R. Biomonitoring of chemical elements in an urban environment using arboreal and bush plant species. Environ. Sci. Pollut. Res. 2011, 18, 51-63. [CrossRef] [PubMed]

11. Ugolini, F.; Tognetti, R.; Raschi, A.; Bacci, L. Quercus ilex L. as bioaccumulator for heavy metals in urban areas: Effectiveness of leaf washing with distilled water and considerations on the trees distance from traffic. Urban For. Urban Green. 2013, 12, 576-584. [CrossRef]

12. Leonard, R.J.; McArthur, C.; Hochuli, D.F. Particulate matter deposition on roadside plants and the importance of leaf trait combinations. Urban For. Urban Green. 2016, 20, 249-253. [CrossRef]

13. Petschinger, K.; Adlassnig, W.; Sabovljevic, M.S.; Lang, I. Lamina cell shape and cell wall thickness are useful indicators for metal tolerance-an example in bryophytes katharina. Plants 2021, 10, 274. [CrossRef] [PubMed]

14. Cocozza, C.; Ravera, S.; Cherubini, P.; Lombardi, F.; Marchetti, M.; Tognetti, R. Integrated biomonitoring of airborne pollutants over space and time using tree rings, bark, leaves and epiphytic lichens. Urban For. Urban Green. 2016, 17, 177-191. [CrossRef]

15. Vlachokostas, C.; Michailidou, A.V.; Matziris, E.; Achillas, C.; Moussiopoulos, N. A multiple criteria decision-making approach to put forward tree species in urban environment. Urban Clim. 2014, 10, 105-118. [CrossRef]

16. Madejón, P.; Ciadamidaro, L.; Marañón, T.; Murillo, J.M. Long-term biomonitoring of soil contamination using poplar trees: Accumulation of trace elements in leaves and fruits. Int. J. Phytoremediation 2013, 2, 602-614. [CrossRef] [PubMed]

17. Berlizov, A.N.; Blum, O.B.; Filby, R.H.; Malyuk, I.A.; Tryshyn, V.V. Testing applicability of black poplar (Populus nigra L.) bark to heavy metal air pollution monitoring in urban and industrial regions. Sci. Total Environ. 2007, 372, 693-706. [CrossRef] [PubMed]

18. Chrabaszcz, M.; Mróz, L. Tree bark, a valuable source of information on air quality. Pol. J. Environ. Stud. 2017, 2, 453-466. [CrossRef] 
19. Mori, J.; Hanslin, H.M.; Burchi, G.; Sæbø, A. Particulate matter and element accumulation on coniferous trees at different distances from a highway. Urban For. Urban Green. 2015, 14, 170-177. [CrossRef]

20. Tomasevic, M.; Rajsic, S.; Dorcevic, D.; Tasic, M.; Krstic, J.; Novakovic, V. Heavy metals accumulation in tree leaves from urban areas. Environ. Chem. Lett. 2004, 2, 151-154. [CrossRef]

21. Assad, M.; Parelle, J.; Cazaux, D.; Gimbert, F.; Chalot, M.; Tatin-Froux, F. Mercury uptake into poplar leaves. Chemosphere 2016, 146, 1-7. [CrossRef]

22. Yalaltdinova, A.; Kim, J.; Baranovskaya, N.; Rikhvanov, L. Populus nigra L. as a bioindicator of atmospheric trace element pollution and potential toxic impacts on human and ecosystem. Ecol. Indic. 2018, 95, 974-983. [CrossRef]

23. Chandra, R.; Kang, H. Mixed heavy metal stress on photosynthesis, transpiration rate, and chlorophyll content in poplar hybrids. For. Sci. Technol. 2016, 12, 55-61. [CrossRef]

24. He, J.; Ma, C.; Ma, Y.; Li, H.; Kang, J.; Liu, T.; Polle, A.; Peng, C.; Luo, Z.B. Cadmium tolerance in six poplar species. Environ. Sci. Pollut. Res. 2012, 20, 163-174. [CrossRef] [PubMed]

25. Lepp, N.W.; Madejón, P. Cadmium and zinc in vegetation and litter of a voluntary woodland that has developed on contaminated sediment-derived soil. J. Environ. Qual. 2007, 36, 1123-1131. [CrossRef]

26. Unterbrunner, R.; Puschenreiter, M.; Sommer, P.; Wieshammer, G.; Tlustoš, P.; Zupan, M.; Wenzel, M.M. Heavy metal accumulation in trees growing on contaminated sites in Central Europe. Environ. Pollut. 2007, 148, 107-114. [CrossRef] [PubMed]

27. Adams, J.P.; Adeli, A.; Hsu, C.-Y.; Harkess, R.L.; Page, G.P.; de Pamphilis, C.W.; Schultz, E.B.; Yuceer, C. Poplar maintains zinc homeostasis with heavy metal genes HMA4 and PCS1. J. Exp. Bot. 2011, 62, 3737-3752. [CrossRef] [PubMed]

28. Sebastiani, L.; Francini, A.; Romeo, S.; Ariani, A.; Minnocci, A. Heavy Metals Stress on Poplar: Molecular and Anatomical Modifications. In Approaches to Plant Stress and Their Management; Gaur, R.K., Sharma, P., Eds.; Springer: New Delhi, India, 2014; pp. 267-279.

29. Emami, A.S.; Kouchaksaraei, M.T.; Bahramifar, N.; Salehi, A. Gas exchange responses of two poplar clones (Populus euramericana (Dode) Guinier 561/41 and Populus nigra Linnaeus 63/135) to lead toxicity. J. For. Sci. 2016, 62, 422-428.

30. Han, Y.; Wang, W.; Sun, J.; Ding, M.; Zhao, R.; Deng, S.; Wang, F.; Hu, Y.; Wang, Y.; Lu, Y.; et al. Populus euphratica XTH overexpression enhances salinity tolerance by the development of leaf succulence in transgenic tobacco plants. J. Exp. Bot. 2013, 64, 4225-4238. [CrossRef]

31. Pajevic, S.; Borisev, M.; Nikolic, N.; Krstic, B.; Pilipović, A.; Orlović, S. Phytoremediation capacity of poplar (Populus spp.) and willow (Salix spp.) clones in relation to photosynthesis. Arch. Biol. Sci. 2009, 61, 239-247. [CrossRef]

32. Barbeş, L.; Bărbulescu, A.; Rădulescu, C.; Stihi, C.; Chelarescu, E.D. Determination of heavy metals in leaves and bark of Populus nigra L by atomic absorption spectrometry. Rom. Rep. Phys. 2014, 66, 877-886.

33. Madejón, P.; Maranon, T.; Murillo, J.M.; Robinson, B. White poplar (Populus alba) as a biomonitor of trace elements in contaminated riparian forests. Environ. Pollut. 2004, 132, 145-155. [CrossRef] [PubMed]

34. Utmazian, M.N.D.S.; Wenzel, W.W. Cadmium and zinc accumulation in willow and poplar species grown on polluted soils. J. Plant Nutr. Soil Sci. 2007, 170, 265-272. [CrossRef]

35. Pilipović, A.; Zalesny, R.S., Jr.; Orlović, S.; Drekić, M.; Pekeč, S.; Katanić, M.; Poljaković-Pajnik, L. Growth and physiological responses of three poplar clones grown on soils artificially contaminated with heavy metals, diesel fuel, and herbicides. Int. J. Phytoremediation 2020, 22, 436-450. [CrossRef] [PubMed]

36. Silva, N.A.F.; Lopes, M.I.; Leitao, R.A.E.; Silva, H.F.A.; Matos, M.J. Simultaneous monitoring of toxic metals on white poplar (Populus) by SWASV. J. Braz. Chem. Soc. 2005, 16, 1275-1282. [CrossRef]

37. Yang, Q.; Wang, H.; Wang, J.; Lu, M.; Liu, C.; Xia, X.; Yin, W.; Guo, H. $\mathrm{PM}_{2.5}$-bound $\mathrm{SO}_{4}{ }^{2-}$ absorption and assimilation of poplar and its physiological responses to $\mathrm{PM}_{2.5}$ pollution. Environ. Exp. Bot. 2018, 153, 311-319. [CrossRef]

38. Directive 2008/50/EC of the European Parliament and of the Council of 21 May 2008 on Ambient Air Quality and Cleaner Air for Europe. Available online: https:/ / eur-lex.europa.eu/legal-content/en/ALL/?uri=CELEX\%3A32008L0050 (accessed on 11 November 2020).

39. Directive 2004/107/EC of the European Parliament and of the Council of 15 December 2004 Relating to Arsenic, Cadmium, Mercury, Nickel and Polycyclic Aromatic Hydrocarbons in Ambient Air. Available online: https://eur-lex.europa.eu/legalcontent/EN/TXT/PDF/?uri=CELEX:32004L0107\&from=EN (accessed on 11 November 2020).

40. Kousehlar, M.; Widom, E. Sources of metals in atmospheric particulate matter in Tehran, Iran: Tree bark biomonitoring. Sci. Total Environ. 2019, 104, 71-82. [CrossRef]

41. Farsani, M.H.; Shirmardi, M.; Alavi, N.; Maleki, H.; Sorooshian, A.; Babaei, A.; Asgharnia, H.; Marzouni, M.B.; Goudarzi, G. Evaluation of the relationship between $\mathrm{PM}_{10}$ concentrations and heavy metals during normal and dusty days in Ahvaz, Iran. Aeolian Res. 2018, 33, 12-22. [CrossRef]

42. Pandey, M.; Pandey, A.K.; Mishra, A.; Tripathi, B.D. Speciation of carcinogenic and non-carcinogenic metals in respirable suspended particulate matter $\left(\mathrm{PM}_{10}\right)$ in Varanasi, India. Urban Clim. 2017, 19, 141-154. [CrossRef]

43. Di Vaio, P.; Magli, E.; Caliendo, G.; Corvino, A.; Fiorino, F.; Frecentese, F.; Saccone, I.; Santagada, V.; Severino, B.; Onorati, G.; et al. Heavy metals size distribution in $\mathrm{PM}_{10}$ and environmental-sanitary risk analysis in Acerra (Italy). Atmosphere 2018, 9, 58. [CrossRef]

44. Juda-Rezler, K.; Reizera, M.; Maciejewska, K.; Błaszczak, B.; Klejnowski, K. Characterization of atmospheric PM2.5 sources at a Central European urban background site. Sci. Total Environ. 2020, 713, 136729. [CrossRef] 
45. Summak, G.; Ozdemir, H.; Oruc, I.; Kuzu, L.; Saral, A.; Demir, G. Statistical evaluation and predicting the possible sources of particulate matter in a Mediterranean metropolitan city. Glob. Nest J. 2018, 20, 173-180.

46. Alahabadi, A.; Ehrampoush, M.H.; Miri, M.; Aval, H.E.; Yousefzadeh, S.; Ghaffari, H.R.; Ahmadi, E.; Talebi, P.; Fathabadi, Z.A.; Babai, F.; et al. A comparative study on capability of different tree species in accumulating heavy metals from soil and ambient air. Chemosphere 2017, 172, 459-467. [CrossRef] [PubMed]

47. Hajar, E.W.I.; Sulaiman, A.Z.B.; Sakinah, A.M.M. Assessment of heavy metals tolerance in leaves, stems and flowers of Stevia rebaudiana plant. Procedia Environ. Sci. 2014, 20, 386-393. [CrossRef]

48. Liu, Y.; Yang, Z.; Zhu, M.; Yin, J. Role of plant leaves in removing airborne dust and associated metals on Beijing roadsides. Aerosol Air Qual. Res. 2017, 17, 2566-2584. [CrossRef]

49. Tsonev, T.; Lidon, F.J.C. Zinc in plants-An overview. Emir. J. Food Agric. 2012, 24, 322-333.

50. Negral, L.; Suarez-Pena, B.; Zapico, E.; Fernandez-Nava, Y.; Megido, L.; Moreno, J.; Maranon, E.; Castrillon, L. Anthropogenic and meteorological influences on PM10 metal/semimetal concentrations: Implications for human health. Chemosphere 2020, 243, 125347. [CrossRef] [PubMed]

51. Miri, M.; Ehrampoush, M.H.; Ghaffari, H.R.; Aval, H.E.; Rezai, M.; Najafpour, F.; Fathabadi, Z.A.; Aval, M.Y.; Ebrahimi, A. Atmospheric heavy metals biomonitoring using a local Pinus eldarica tree. Health Scope 2016, 6, 1-9. [CrossRef]

52. Norouzi, S.; Khademi, H.; Cano, A.F.; Acosta, J.A. Using plane tree leaves for biomonitoring of dust borne heavy metals: A case study from Isfahan, Central Iran. Ecol. Indic. 2015, 57, 64-73. [CrossRef]

53. Hajizadeh, Y.; Mokhtari, M.; Faraji, M.; Abdolahnejad, A.; Mohammadi, A. Biomonitoring of airborne metals using tree leaves: Protocol for biomonitor selection and spatial trend. MethodsX 2019, 6, 1694-1700. [CrossRef] [PubMed]

54. Nadgorska-Socha, A.; Kandziora-Ciupa, M.; Trzesicki, M.; Barczyk, G. Air pollution tolerance index and heavy metal bioaccumulation in selected plant species from urban biotopes. Chemosphere 2017, 183, 471-482. [CrossRef]

55. Liu, Y.J.; Zhu, Y.G.; Ding, H. Lead and cadmium in leaves of deciduous trees in Beijing, China: Development of a metal accumulation index (MAI). Environ. Pollut. 2007, 145, 387-390. [CrossRef] [PubMed]

56. de Paula, P.H.; Mateus, V.L.; Araripe, D.R.; Duyck, C.B.; Saint'Pierre, T.D.; Gioda, A. Biomonitoring of metals for air pollution assessment using a hemiepiphyte herb (Struthanthus flexicaulis). Chemosphere 2015, 138, 429-437. [CrossRef] [PubMed]

57. Wilks, D.S. Statistical Methods in the Atmospheric Sciences, 4th ed.; Elsevier: Cambridge, MA, USA, 2019 ; pp. $617-668$.

58. Bican-Brisan, N.; Enache, T.; Rosu, C. Concentration of particulate matter associated to a crossroad traffic from Cluj-Napoca city. Studia UBB Chem. 2013, 63, 253-264.

59. Borghi, F.; Spinazze, A.; Campagnolo, D.; Rovelli, S.; Cattaneo, A.; Cavallo, D.M. Precision and accuracy of a direct-reading miniaturized monitor in PM2.5 exposure assessment. Sensors 2018, 18, 3089. [CrossRef]

60. Borghi, F.; Fanti, G.; Spinazze, A.; Campagnolo, D.; Rovelli, S.; Keller, M.; Cattaneo, A.; Cavallo, D.M. Evaluation of personal exposure to air pollutants and estimation of the inhaled dose for commuters in the urban area of Milan, Italy. Proceedings 2019, 44, 6307. [CrossRef]

61. Jimoda, L.A.; Adeniran, J.A.; Aladeokin, V.O.; Ayantoyinbo, B.B. Particulate concentration around busy traffic locations in Ogbomoso, Nigeria. LAUJET 2014, 8, 45-51.

62. Aliyar, Z.B.; Shafiei, A.B.; Seyedi, N.; Rezapour, S.; Moghanjugi, S.M. Effect of traffic-induced air pollution on seed germination of Arizona Cypress (Cupressus arizonica Green) and Black Pine (Pinus nigra Arnold). Urban For. Urban Green. 2020, 55, 126841. [CrossRef]

63. De La Cruz, A.R.H.; Ferreira, L.D.S.C.; Andrade, V.P.; Gioda, A. Biomonitoring of toxic elements in plants collected near leather tanning industry. J. Braz. Chem. Soc. 2019, 30, 256-264. [CrossRef]

64. Buchmann, J.H.; de Souza Sarkis, J.E.; Rodrigues, C. Determination of metals in plant samples by using a sector field inductively coupled plasma mass spectrometer. Sci. Total Environ. 2000, 263, 221-229. [CrossRef]

65. Rudnick, R.L.; Gao, S. Composition of the continental crust. In Treatise on Geochemistry, 2nd ed.; Holland, H.D., Turekian, K.K., Eds.; Elsevier: San Diego, CA, USA, 2014; Volume 4, pp. 1-51.

66. Doganlar, Z.B.; Doganlar, O.; Erdogan, S.; Onal, Y. Heavy metal pollution and physiological changes in the leaves of some shrub, palm and tree species in urban areas of Adana, Turkey. Chem. Speciat. Bioavailab. 2012, 24, 65-78. [CrossRef] 